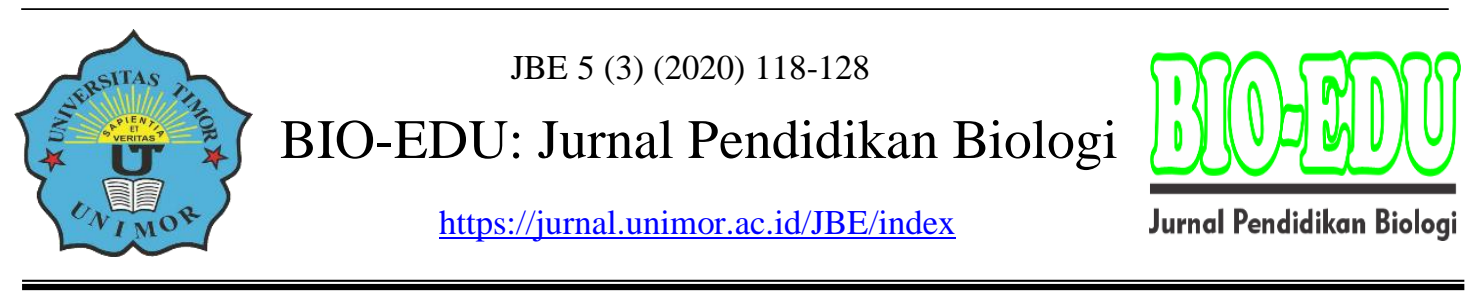

\title{
Stomach Content Analysis of Tilapia Fish (Oreochromis mossambicus) in Talaga Lake Waters Donggala Regency
}

\section{Analisis Isi Lambung Ikan Mujair (Oreochromis mossambicus) di Perairan Danau Talaga Kabupaten Donggala}

\author{
Dirham $^{1}$, Manap Trianto \\ ${ }^{1}$ Program Studi Pendidikan Biologi, Fakultas Keguruan dan Ilmu Pendidikan, \\ Universitas Tadulako \\ ${ }^{2}$ Fakultas Biologi, Universitas Gadjah Mada \\ E-mail: dirhamfaried@gmail.com
}

DOI: https://DOI 10.32938/jbe. v5i3.727

\begin{abstract}
Abstrak
Ikan mujair (Oreochromis mossambicus) merupakan jenis ikan konsumsi air tawar, bentuk badan pipih dengan warna abu-abu, coklat atau hitam. Penelitian ini perlu dilakukan untuk mengetahui kebiasaan makan ikan mujair di alam. Tujuan penelitian ini adalah untuk mendeskripsikan jenis-jenis makanan yang ditemukan dilambung ikan mujair (Oreochromis mossambicus) yang terdapat di Perairan Danau Talaga Kabupaten Donggala. Penelitian ini dilaksanakan pada bulan April 2019. Metode yang digunakan dalam peneltian ini adalah metode frekuensi kejadian volumetrik dengan pengambilan sampel melalui pembedahan ikan untuk mengambil lambungnya dan dianalisis. Berdasarkan hasil analisis isi lambung ikan Mujair (Oreochromis mossambicus), diperoleh dua kelompok pakan yaitu pakan Nabati (Fitoplaknton) berupa Navicula placentula, Schroederia segitera, Schoroederia anchora, Zignemopsis circumcaniratum, Anabaena sp., Oscillatoria princeps, Spirogyra protifica, Bacillaria sp., Nitzschia aetinastroides, Oedogonium sp., Coelastrum chodati, dan pakan hewani (Zooplankton) berupa Tubipex sp., Brachionus havanaensis, Cyclops sp., Carcinus sp., Arcella sp., Acetes sp.
\end{abstract}

Kata Kunci: Danau Talaga; ikan mujair; isi lambung; Kabupaten Donggala; pakan

\begin{abstract}
Tilapia fish (Oreochromis mossambicus) is a type of freshwater consumption fish, flat body shape with grey, brown or black colour. This research needs to be done to determine the eating habits of tilapia fish in nature. The purpose of this study was to describe the types of food found in the stomach of tilapia fish (Oreochromis mossambicus) in Talaga Lake, Donggala Regency. This research was conducted in April 2019. The method used in this study was a volumetric occurrence frequency method by a surgical sampling of fish to extract the stomach and analyze it. Based on the results of the analysis of the stomach contents of the Mujair fish (Oreochromis mossambicus), two groups of feed were obtained, namely Vegetable food (Fitoplaknton) in the form of Navicula placentula, Schroederia segitera, Schoroederia anchora, Zignemopsis circumcaniratum, Anabaena sp, Oscillatoria princeps, Spirogyra protifica, Bacillaria sp., Nitzschia aetinastroides, Oedogonium sp., Coelastrum chodati, and animal feed (Zooplankton) in the form of Tubipex sp., Brachionus havanaensis, Cyclops sp., Carcinus sp., Arcella sp., Acetes sp.
\end{abstract}

Keywords: Talaga Lake; tilapia fish; stomach contents; Donggala Regency; feed 


\section{PENDAHULUAN}

Indonesia merupakan negara yang terdiri dari perairan tawar sangat luas dan berpotensi besar untuk proses budidaya berbagai jenis ikan air tawar (Titrawani et al., 2013: 85; Trianto et al., 2020: 21-29). Perairan umum yang terdiri dari sungai, waduk dan rawa dengan total luas 141.690 hektar merupakan salah satu bentuk dari pengembangan sumber daya perairan di Indonesia (Cahyono, 2000: 23-30; Trianto dan Marisa, 2020: 2933). Habitat air tawar dapat dibedakan atas dua golongan yaitu perairan mengalir atau habitat lotik, misalnya sungai dan perairan menggenang atau lentik, misalnya: kolam, rawa dan danau (Yeni dan Elvira, 2017: 44-49).

Danau merupakan wilayah yang menempati porsi sangat penting dalam menunjang kehidupan manusia, misalnya untuk rekreasi, pertanian, air minum dan kebutuhan manusia lainnya (Tresna et al., 2012: 163-173; Trianto et al., 2020: 199-209). Menurut Gani et al. (2015: 9-18), perairan danau merupakan salah satu bentuk ekosistem air tawar yang terdiri dari berbagai organisme didalamnya. Secara fisik danau dikatakan sebagai tempat yang sangat luas, mempunyai air yang tetap, jernih atau beragam dengan aliran tertentu tergantung kondisi lingkungan. Wulandari (2006: 12-28) menyatakan bahwa danau adalah wilayah badan air yang pada umumnya dikelilingi oleh daratan dan dapat dikelompokkan sebagai salah satu jenis lahan basah. Danau mempunyai berbagai fungsi yang sangat tinggi. Salah satu fungsi danau adalah dalam sektor perikanan, baik budidaya maupun perikanan tangkap. Danau juga sebagai sumber daya alam yang mempunyai potensi yang cukup banyak atau sebagai multifungsi yang baik untuk memenuhi kebutuhan hidup sehari-hari masyarakat disekitarnya, salah satu yang menempati danau adalah ikan (Odum, 1994: 105-200).

Ikan merupakan organisme akuatik yang sangat rentan dengan adanya perubahan lingkungan, terutama yang diakibatkan oleh adanya buangan limbah cair atau padat hasil aktivitas manusia ke dalam perairan, baik secara langsung maupun tidak langsung. Limbah-limbah hasil buangan tersebut sangat mempengaruhi kondisi dan kualitas perairan, baik secara fisik, kimia, maupun biologi. Lebih lanjut hal tersebut juga dapat mempengaruhi kehidupan dan pola sebaran jenis ikan dalam suatu perairan (Titrawani et al., 2013: 85; Suprianto et al., 2020: 30-39). Effendie (2002: 25-30) menjelaskan bahwa pakan merupakan salah satu hal yang dapat mempengaruhi jumlah populasi ikan di perairan. Beberapa faktor yang berhubungan secara langsung dengan hal tersebut yaitu jumlah dan kualitas pakan yang tersedia serta mudah tidaknya didapatkan. Jenis-jenis pakan alami yang dimakan ikan sangat bermacam-macam, bergantung pada jenis ikan dan tingkat umurnya. Benih ikan yang baru mencari makan biasanya memiliki jenis makanan utama berupa plankton jenis nabati (fitoplankton) namun sejalan dengan bertambah besarnya ikan berubah pula makanannya (Sjafei, 2001: 7-11).

Makanan sebagai komponen penting bagi kehidupan organisme perairan merupakan faktor ekologis penting yang dapat menentukan tingkat kepadatan populasi, reproduksi, pertumbuhan, dinamika populasi, dan kondisi ikan (Mardlijah, 2017: 227235; Trianto et al., 2020: 154-162). Jenis makanan suatu spesies ikan biasanya berhubungan erat dengan umur, tempat dan waktu keberadaan ikan tersebut diperairan. Kebiasaan makan ikan dapat dilihat dari hubungan ekologi diantara organisme di dalam perairan, misalnya bentuk-bentuk pemangsaan, persaingan dan rantai makanan (Effendie, 2002: 54).

Kalara (2002: 43-51) menyatakan bahwa di Danau Talaga, Kecamatan Dampelas, Kabupaten Donggala terdapat 10 jenis ikan yaitu Orechromis mossambicus, Oreochromis niloticus, Osteochilllus hasselti, Puntius javanicus, Clarias batracus, Ciprinus carpio, 
Channa striata, Anabas testudineus, Trichogaster trichopterus dan Angulla mauritiana. Sektor perikanan air tawar sebagai konsumsi masyarakat merupakan sumber daya perairan yang terbesar di Danau Talaga. Penghasilan masyarakat sekitar Danau Talaga sangat bergantung pada sektor perikanan dari danau, tetapi pengetahuan masyarakat tentang Pengelolaan Sumber daya Ikan (SDI) yang sangat minim menyebabkan makin berkurangnya produksi ikan di Danau Talaga yang berakibat pada penurunan nilai perekonomian masyarakat setempat (Barani, 2002: 57-60).

Perairan Danau Talaga yang terletak di daerah Pantai Barat, Kabupaten Donggala, tepatnya di Desa Talaga, Kecamatan Dampelas, sekitar 143 kilometer sebelah utara kota Palu mempunyai posisi strategis dan berfungsi serbaguna bagi kehidupan masyarakat disekitar danau. Selain dimanfaatkan oleh struktur perikanan juga dimanfaatkan untuk struktur pariwisata. Sedangkan di sekitar danau telah dijadikan sebagai areal permukiman dan sepanjang tepi danau banyak ditumbuhi pohon sagu yang secara sengaja ditanam oleh masyarakat setempat sejak lama sebagai salah satu sumber pangan. Perairan Danau Talaga juga terdapat beberapa jenis ikan, diantaranya yaitu jenis ikan mujair, ikan gabus, ikan lele dan ikan mas.

Perairan Danau Talaga dimanfaatkan oleh masyarakat sekitar untuk kegiatan sehari-hari seperti mandi dan mencuci. Aktivitas masyarakat tersebut dapat menimbulkan berbagai permasalahan lingkungan yang serius bagi Danau Talaga. Beban pencemar yang dominan di Danau Talaga pada umumnya akibat dari konsentrasi bahan organik yang berasal dari limbah domestik. Sehingga dapat menyebabkan penurunan kualitas perairannya. Berdasarkan penjelasan tersebut diatas, ikan mujair (Oreochromis mossambicus) yang berada diperairan Danau Talaga dapat dikatakan sangat bermanfaat dalam memenuhi kebutuhan ekonomi, mempunyai populasi ikan mujair yang cukup banyak dibandingkan dengan ikan lainnya, serta masih kurangnya penelitian tentang kajian isi lambung ikan di Danau Talaga, sehingga peneliti mengambil ikan mujair (Oreochromis mossambicus) sebagai bahan penelitian mengenai analisis isi lambung ikan guna untuk mengetahui jenis-jenis makanan yang ditemukan dalam lambung ikan mujair yang berada di perairan Danau Talaga Kabupaten Donggala dengan adanya penelitian ini dapat menambah wawasan khususnya dalam bidang Iktiologi.

\section{METODE}

\section{Waktu dan Tempat Penelitian}

Penelitian ini dilaksanakan pada bulan April 2019 di Danau Talaga Kecamatan Dampelas, Kabupaten Donggala menggunakan metode frekuensi kejadian volumetrik dengan pengambilan sampel melalui pembedahan ikan untuk mengambil lambungnya dan dianalisis. Selanjutnya, analisis isi lambung ikan mujair dilaksanakan di Laboratorium Biologi, Fakultas Keguruan dan Ilmu Pendidikan, Universitas Tadulako.

\section{Alat dan Bahan}

Alat-alat yang digunakan dalam penelitian adalah perahu, pancing, termometer, salinometer, alat bedah, pemotong, cawan petri, PH meter, DO meter, botol roll film, kaca objek, kaca penutup, lup, mikroskop, pipet tetes, buku identifikasi, ember, alat tulis. Bahan-bahan yang digunakan dalam penelitian adalah ikan mujair 25 ekor, formalin, alkohol, aquades, lap/tisu gulung.

\section{Pelaksanaan Penelitian}

Pengambilan Sampel 
Tahap pertama, merupakan kegiatan lapangan yang meliputi penangkapan ikan mujair (Oreochromis mossambicus). Penangkapan ikan dilakukan dengan beberapa cara yaitu dengan menggunakan pancing, jaring dan dengan memanah. Kemudian, ikan yang telah terangkap akan dibedah dengan alat bedah untuk mengambil lambung ikan tersebut. Lalu dimasukan ke dalam botol rol film.

Pengukuran Kondisi Fisik Kimia Perairan

Tahap kedua, menentukan kondisi fisik-kimia di Perairan Danau Talaga Kabupaten Donggala, dengan cara melakukan pengukuran kondisi fisik kimia perairan. Parameter yang diukur di lapangan adalah suhu air dengan menggunakan termometer, salinitas dengan menggunakan salinometer, DO terlarut dengan menggunakan DO meter dan $\mathrm{pH}$ air dengan menggunakan $\mathrm{pH}$-meter.

Pengambilan Data Spesimen dari Isi Lambung Ikan

Tahap ketiga, dilakukan di Laboratorium Biologi, Fakultas Keguruan dan Ilmu Pendidikan, Universitas Tadulako. Hal yang dilakukan yaitu berupa pengambilan data spesimen-spesimen dari isi lambung ikan yang didapat. Selanjutnya, spesimen yang telah didapat di letakkan pada cawan petri. Kemudian, ditempatkan pada kaca objek dan ditutup dengan kaca penutup, lalu diamati dibawah mikroskop.

\section{Analisis Data}

Analisis isi lambung Ikan Mujair dilakukan dengan menggunakan Index of Preponderance atau Indeks Bagian Terbesar.

$$
\mathrm{IP}=\mathrm{Vi} \times \mathrm{Oi} / \Sigma(\mathrm{Vi} \times \mathrm{Oi}) \times 100 \%
$$

Keterangan :

IP = Index of Preponderance

Vi $\quad=$ Persentase volume satu macam makanan

Oi $\quad=$ Persentase frekuensi kejadian satu macam makanan

$\Sigma \quad=$ Jumlah Vi x Oi dari semua macam makanan.

Persentase volume dinyatakan dengan cara menghitung volume makanan sejenis per volume makanan seluruhnya.

$$
\mathrm{Vi}=\text { Volume makanan sejenis / Volume seluruh jenis x 100\% }
$$

\section{HASIL DAN PEMBAHASAN}

\section{Hasil}

\section{Kondisi Fisik Kimia Perairan Danau Talaga}

Kondisi fisik kimia perairan sangat diperlukan untuk mengetahui ciri-ciri suatu perairan serta dapat dijadikan sebagai dasar untuk menentukan tercemar atau tidaknya perairan tersebut yang sangat erat hubungannya dengan kehidupan organisme di perairan (Mamu, 2007: 44-67). Hasil pengukuran kondisi fisik kimia Perairan Danau Talaga dapat dilihat pada Tabel 1.

Tabel 1. Hasil pengukuran kondisi fisik kimia Perairan Danau Talaga

\begin{tabular}{clc}
\hline No & \multicolumn{1}{c}{ Parameter } & Nilai Kisaran \\
\hline 1 & Suhu $\left({ }^{0} \mathrm{C}\right)$ & $30,3-32,5$ \\
2 & $\mathrm{pH}$ & $7,9-8,2$ \\
3 & Kecerahan $(\mathrm{m})$ & $2,5-3,5$ \\
4 & Salinitas $(\%)$ & $0,2-0,5$ \\
5 & Oksigen Terlarut $(\mathrm{mg} / \mathrm{l})$ & $4,62-5,25$ \\
\hline
\end{tabular}




\section{Jenis Makanan Ikan Mujair (Oreochromis mossambicus)}

Adapun jenis makanan ikan mujair (Oreochromis mossambicus) di perairan Danau Talaga Kabupaten Dongggala terdiri atas dua kelompok yaitu nabati (Fitoplankton) terdiri atas 8 spesies (Gambar 1) dan hewani (Zooplankton) terdiri atas 4 spesies (Gambar 2).
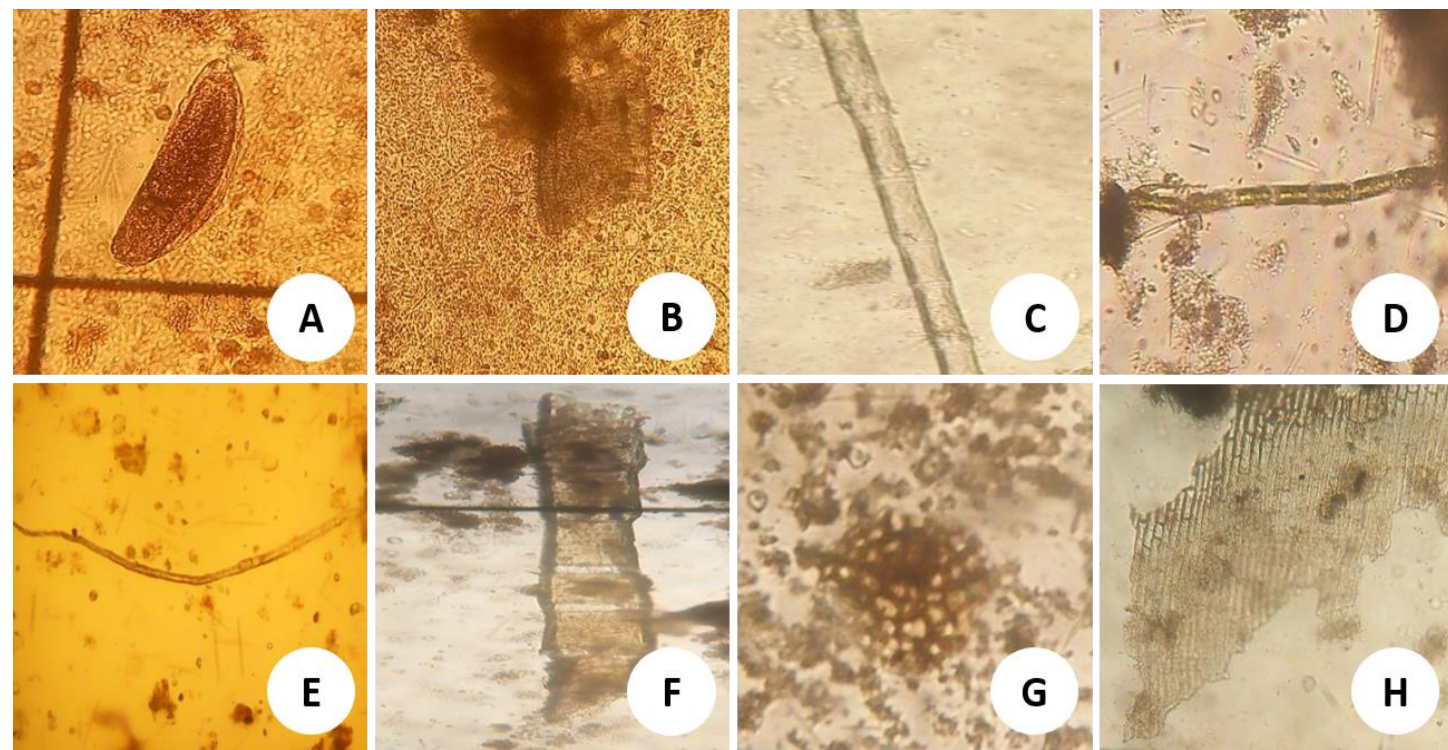

Gambar 1. Jenis makanan nabati (Fitoplankton) ikan mujair (Oreochromis mossambicus); A. Navicula placentula, B. Oscillatoria princeps, C. Zygnemopsis circumcarinatum, D. Anabaena sp., E. Schroederia segitera, F. Oedogonium sp., G. Coelastrum chodati, dan H. Bacillaria sp.
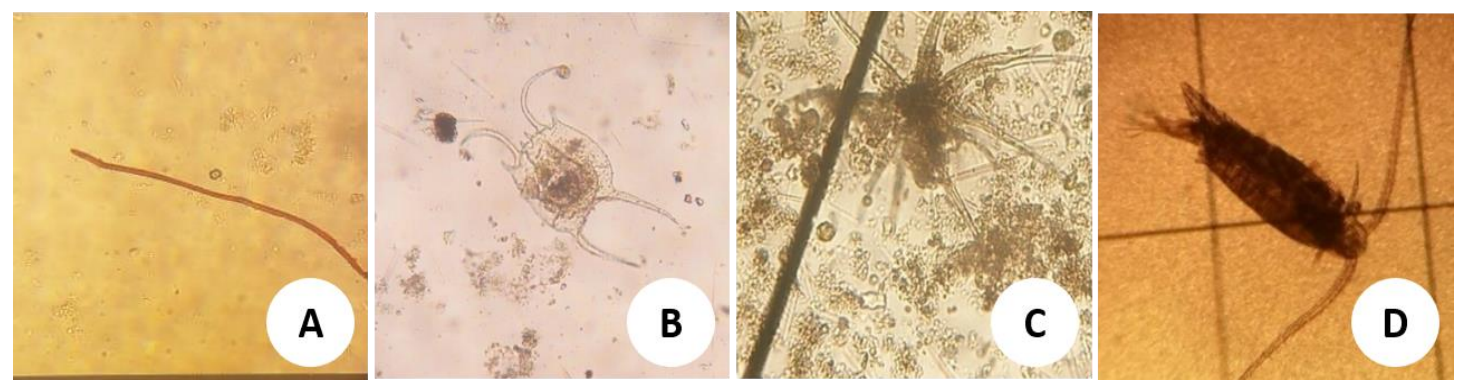

Gambar 2. Jenis makanan hewani (Zooplankton) ikan mujair (Oreochromis mossambicus); A. Tubifex sp., B. Brachionus havanaensis, C. Carcinus sp., dan D. Temora sp.

Kehadiran Jenis Makanan Ikan Mujair (Oreochromis mossambicus)

Adapun kehadiran jenis makanan ikan mujair (Oreochromis mossambicus) di perairan Danau Talaga Kabupaten Donggala dapat dilihat pada Tabel 2.

Tabel 2. Kehadiran Jenis Makanan Ikan Mujair (Oreochromis mossambicus)

\begin{tabular}{cccccccccccccc}
\hline \multirow{2}{*}{ Ikan } & 1 & 2 & 3 & 4 & 5 & 6 & 7 & 8 & 9 & 10 & 11 & 12 & $\sum$ \\
\hline 1 & $\sqrt{ }$ & $\sqrt{ }$ & $\sqrt{ }$ & $\sqrt{ }$ & $\sqrt{ }$ & & & & & & $\sqrt{ }$ & 6 \\
2 & & & & & $\sqrt{ }$ & $\sqrt{ }$ & & & & $\sqrt{ }$ & & & 3
\end{tabular}




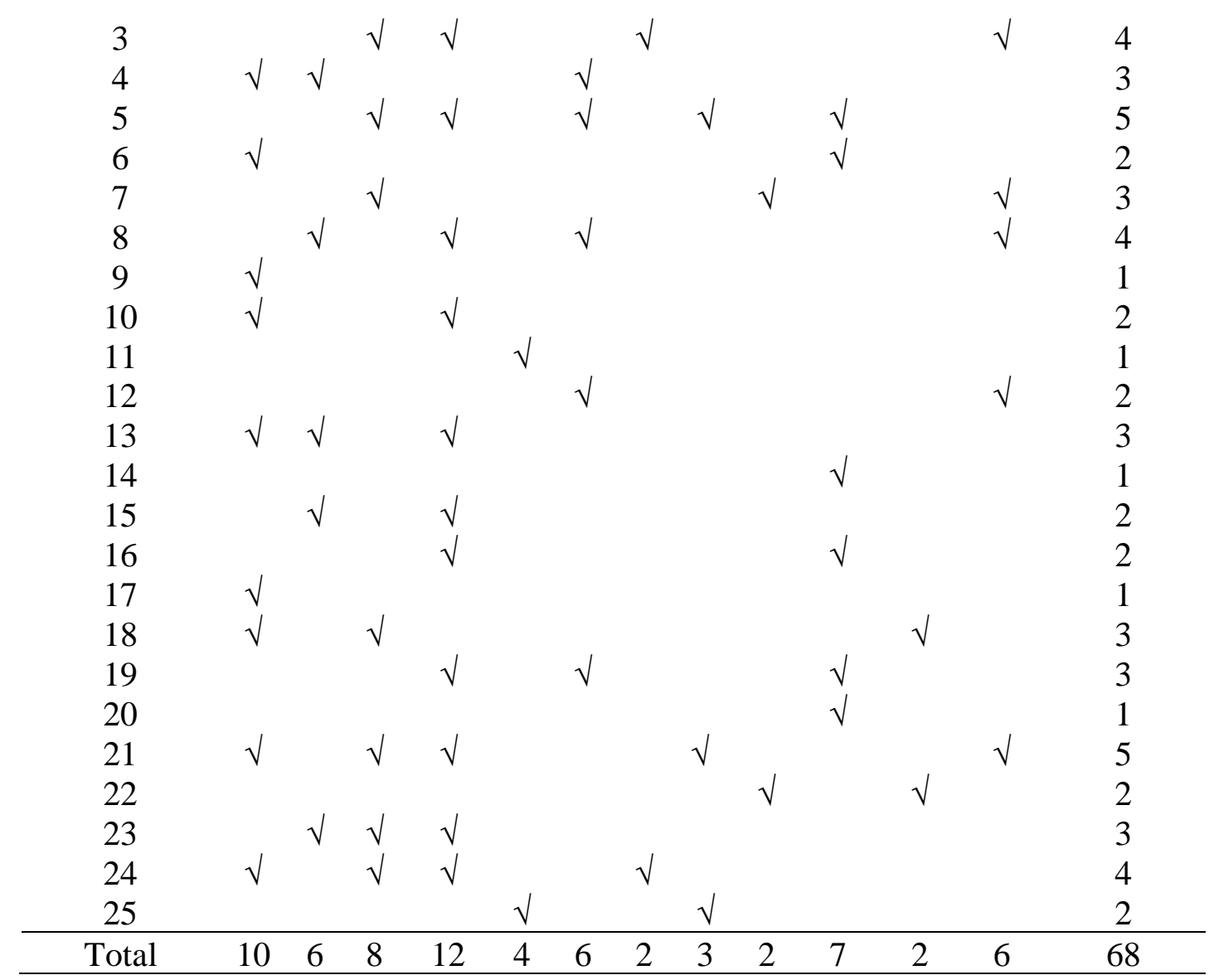

Keterangan nama jenis:

1. Navicula placentula

8. Bacillaria sp.

2. Tubipex sp.

9. Carcinus sp.

3. Schoroederia segitera

10. Oedogonium sp.

4. Zignemopsis circumcarinatum

11. Coelastrum chodati

5. Anabaena sp.

12. Temora sp.

6. Brachionus havanaensis

7. Oscillatoria princeps

Persentase Volume dan Frekuensi Kejadian Jenis Makanan Ikan Mujair (Oreochromis mossambicus)

Adapun persentase volume jenis makanan ikan mujair (Oreochromis mossambicus) di perairan Danau Talaga Kabupaten Dongggala dapat dilihat pada Tabel 3.

Tabel 3. Persentase volume kejadian jenis makanan ikan Mujair (Oreochromis mossambicus)

\begin{tabular}{lcccc}
\hline \multicolumn{1}{c}{ Jenis } & VMS & VSJ & VMS : VSJ & VMS : VSJ x 100\% \\
\hline N. placentula & 10 & 12 & 0.83 & $83 \%$ \\
Tubipex sp. & 6 & 12 & 0.50 & $50 \%$ \\
S. segitera & 8 & 12 & 0.67 & $67 \%$ \\
Z. circumcarinatum & 12 & 12 & 1.00 & $100 \%$ \\
Anabaena sp. & 4 & 12 & 0.33 & $33 \%$
\end{tabular}




\begin{tabular}{lllll} 
B. havanaensis & 6 & 12 & 0.50 & $50 \%$ \\
O. princeps & 2 & 12 & 0.17 & $17 \%$ \\
Bacillaria sp. & 3 & 12 & 0.25 & $25 \%$ \\
Carcinus sp. & 2 & 12 & 0.17 & $17 \%$ \\
Oedogonium sp. & 7 & 12 & 0.58 & $58 \%$ \\
C. chodati & 2 & 12 & 0.17 & $17 \%$ \\
Temora sp. & 6 & 12 & 0.50 & $50 \%$ \\
\hline \multicolumn{1}{c}{ Jumlah } & & & & $567 \%$ \\
\hline
\end{tabular}

Keterangan:

VMS = Volume Makanan Sejenis

VSJ = Volume Seluruh Jenis

Adapun persentase frekuensi kejadian jenis makanan ikan mujair (Oreochromis mossambicus) di perairan Danau Talaga Kabupaten Dongggala dapat dilihat pada Tabel 4.

Tabel 4. Persentase frekuensi kejadian jenis makanan ikan Mujair (Oreochromis mossambicus)

\begin{tabular}{|c|c|c|c|c|}
\hline Jenis & JLB & JSL & JLB : JSL & JLB : JSL x 100\% \\
\hline N. placentula & 10 & 25 & 0.4 & $40 \%$ \\
\hline Tubipex sp. & 6 & 25 & 0.24 & $24 \%$ \\
\hline S. segitera & 8 & 25 & 0.32 & $32 \%$ \\
\hline Z. circumcarinatum & 12 & 25 & 0.48 & $48 \%$ \\
\hline Anabaena sp. & 4 & 25 & 0.16 & $16 \%$ \\
\hline B. havanaensis & 6 & 25 & 0.24 & $24 \%$ \\
\hline O. princeps & 2 & 25 & 0.08 & $8 \%$ \\
\hline Bacillaria sp. & 3 & 25 & 0.12 & $12 \%$ \\
\hline Carcinus sp. & 2 & 25 & 0.08 & $8 \%$ \\
\hline Oedogonium sp. & 7 & 25 & 0.28 & $28 \%$ \\
\hline C. chodati & 2 & 25 & 0.08 & $8 \%$ \\
\hline Temora sp. & 6 & 25 & 0.24 & $24 \%$ \\
\hline \multicolumn{4}{|c|}{ man } & $272 \%$ \\
\hline
\end{tabular}

Keterangan:

JLB = Jumlah Lambung yang berisi satu jenis makanan

JSL = Jumlah seluruh lambung yang berisi makanan

\section{Pembahasan}

\section{Kondisi Fisik dan Kimia Perairan Danau Talaga}

Kondisi lingkungan secara fisik dan kimia sangat diperlukan untuk mengetahui ciri-ciri suatu perairan (Trianto dan Purwanto, 2020: 2619-2628; Trianto dan Purwanto, 2020: 186-193). Kondisi ini juga dapat digunakan sebagai parameter untuk menentukan tercemar atau tidaknya perairan yang hubungannya dengan kehidupan organisme yang ada diperairan tersebut. Berdasarkan hasil pengukuran kondisi fisik kimia perairan Danau Talaga selama penelitian berlangsung. Suhu danau berada pada kisaran $30,3-32,5^{\circ} \mathrm{C}$, untuk wilayah bagian tropis keadaan ini masih dalam batas toleransi dan tidak berpengaruh negatif secara signifikan bagi kehidupan ikan. Hal ini juga sesuai dengan 
pernyataan Mamu (2007: 44) bahwa suhu optimal yang dapat mendukung kehidupan ikan dan organisme perairan lainnya adalah pada kisaran $25-30,5^{\circ} \mathrm{C}$.

Kecerahan air berkisar antara 2,5-3,5 meter. Tingkat kecerahan ini masih tergolong tinggi dan memenuhi syarat bagi kehidupan organisme akuatik. Kecerahan air di bawah $100 \mathrm{~cm}$ (1 meter) terglong tingkat kecerahan rendah (Siregar et al., 2018: 1-15). Semakin dalam lapisan yang dapat ditembus sinar matahari, maka perairan semakin cerah dan semakin baik pula perairan. Berdasarkan pengukuran maka perairan Danau Talaga tergolong perairan sedikit keruh dan berada pada zona limnetik (daerah air terbuka dimana penetrasi cahaya mencapai daerah cukup dalam sehingga efektif untuk fotosintesis). Tingkat kecarahan tersebut sangat mendukung untuk kehidupan ikan dan ketersediaan pakan. Berdasarkan hasil pengukuran tingkat kecerahan perairan danau talaga memiliki kedalaman 3,5 meter (Asyari dan Muflikhah, 2005: 107-112).

Oksigen terlarut yang diukur saat penelitian berkisar antara 4,62-5,25 mg/l. Oksigen terlarut sangat penting bagi pernapasan bagi ikan dan organisme akuatik lainnya (Odum, 1994: 74-81). Kondisi kelarutan oksigen sangat dipengaruhi oleh faktor suhu. Kondisi suhu yang tinggi akan menyebabkan kelarutan oksigen yang rendah dan sebaliknya pada suhu rendah kelarutan oksigen akan meningkat. Setiap spesies biota akuatik pada umumnya mempunyai kisaran toleransi yang berbeda terhadap konsentrasi oksigen terlarut suatu perairan. Ikan merupakan mahkluk air yang membutuhkan kadar oksigen tertinggi. Kadar oksigen terlarut perairan dikatakan optimal dan dapat mendukung kehidupan bagi ikan adalah diatas $5 \mathrm{mg} / \mathrm{l}$, sedangkan apabila ekosistem beriklim sedang maka memerlukan kondisi dengan oksigen terlarut mendekati jenuh. Konsentrasi oksigen yang terlalu rendah akan menyebabkan kematian bagi ikan (Cahyono, 2001: 95). Berdasarkan kriteria tersebut dapat dijelaskan bahwa kandungan oksigen terlarut diperairan Danau Talaga masih cukup tinggi dan layak bagi kehidupan organisme di dalamnya termasuk ikan.

Hasil pengukuran salinitas yang dilakukan di perairan Danau Talaga berada pada kisaran 0,2-0,5\%. Kadar garam atau salinitas di perairan Danau Talaga masih dalam taraf normal untuk mendukung kehidupan ikan dan organisme perairan lainnya. Seperti yang dijelaskan (Susanto, 2004: 150) menyatakan bahwa salinitas air tawar berkisar antara 0 sampai $1 \%$. Berdasarkan kriteria tersebut dapat djelaskan bahwa tingkat salinitas diperairan Danau Talaga masih cukup tinggi dan layak bagi kehidupan organisme di dalamnya termasuk ikan.

Derajat keasaman $(\mathrm{pH})$ yang diperoleh dari hasil pengukuran di perairan Danau Talaga mencapai 7,9-8,2. pH yang ideal bagi ikan antara 6,8 hingga 8,5. Perairan dengan $\mathrm{pH}$ kecil dari 6 merupakan $\mathrm{pH}$ kurang ideal bagi organisme makanan ikan seperti plankton. Nilai pH di bawah 4 akan dapat mematikan ikan (Pescod, 2001: 43-76). Berdasarkan hal tersebut $\mathrm{pH}$ perairan Danau Talaga masih dalam taraf normal untuk mendukung kehidupan biota perairan. Sebagian besar biota akuatik sensitif terhadap perubahan $\mathrm{pH}$ dan menyukai $\mathrm{pH}$ antara 7-8,5. $\mathrm{pH}$ rendah (keasaman yang tinggi) akan menyebabkan penyerapan $\mathrm{O}_{2}$ oleh organisme akan terganggu, karena kandungan $\mathrm{O}_{2}$ terlarut akan kurang, akibatnya konsumsi akan $\mathrm{O}_{2}$ menurun sedangkan aktivitas pernapasan menigkat dan jika keadaan ini terjadi secara terus menerus dapat menyebabkan kematian bagi organisme (Utomo, 2018: 215-235).

\section{Jenis Makanan Ikan Mujair (Oreochromis mossambicus)}

Berdasarkan hasil analisis isi lambung Ikan Mujair (Oreochormis mossambicus), diperoleh dua kelompok pakan yaitu pakan Nabati (Fitoplankton) berupa Navicula 
placentula, Schroederia segitera, Zignemopsis circumcaniratum, Anabaena sp., Oscillatoria princeps, Bacillaria sp., Oedogonium sp., Coelastrum chodati dan pakan hewani (Zooplankton) berupa Tubipex sp., Brachionus havanaensis, Carcinus sp., Temora sp. Kedua kelompok pakan ini hampir selalu ditemukan disetiap lambung ikan mujair. Hasil ini menunjukkan bahwa ikan mujair termasuk dalam golongan pemakan segala atau omnivora (pemakan hewan dan tumbuhan).

Hasil analisis isi lambung ikan mujair menunjukkan bahwa jumlah makanan diperoleh pada setiap lambung berbeda, pada lambung Ikan Mujair ini lebih banyak ditemukan jenis pakan nabati (Fitoplankton) dibanding pakan hewani (Zooplankton). Hal ini sesuai dengan penelitian yang dilakukan oleh Buwono et al. (2019: 8-14) bahwa pada lambung ikan tawes (Barbonymus gonionotus) juga terdapat jenis pakan fitoplankton yang lebih banyak dibandingkan jenis pakan zooplankton.

Selanjutnya, dari jenis pakan nabati (Fitoplankton) jumlah yang paling banyak ditemukan berdasarkan hasil analisa data yaitu jenis spesies Zignemopsis circumcarinatum memiliki nilai IP $3.11 \%$, Navicula placentula memiliki nilai IP $2.51 \%$, Schroederia segitera memilki nilai IP 1.39\%, Oedogonium sp memiliki nilai IP 1.05\%, Bacillaria sp 0,19\%, Oscillatoria princeps 0,09\%, Anabaena sp 0,34\%, Coelastrum chodati $0,09 \%$. Sedangkan pakan hewani (Zooplankton) jumlah yang paling banyak ditemukan yaitu jenis spesies Tubipex sp sebanyak 0,78\%, Brachionus havanaensis $0,78 \%$, Carcinus sp 0,09\% dan Temora sp 0,78\%. Hal ini sesuai dengan yang dijelaskan oleh Tompodung et al. (2016: 20-23) bahwa di alam ikan mujair tidak menunjukkan kesukaan terhadap satu jenis makanan saja melainkan memakan berbagai jenis makanan yang tersedia di perairan danau atau habitatnya. Hal ini sesuai dengan pernyataan Effendie (2002: 18-33) bahwa faktor-faktor yang akan menentukan spesies ikan memakan jenis makanan antara lain ketersediaan jenis makanan tersebut di habitat. Di alam, variasi volume dan frekuensi jenis makanan ikan dipengaruhi oleh jumlah dan ukuran spesies mangsa di lokasi penelitian. Selin itu, adapun yang menyebabkan beberapa lambung terdiri dari sedikit jenis makanan yaitu karena makanan telah tercerna sempurna pada pencernaan ikan atau saat penangkapan ikan tersebut dalam keadaan lapar, sehingga tidak dapat ditemukan jenis makanan dalam jumlah banyak di dalam lambungnya (Sjafei, 2001: 7-11).

\section{KESIMPULAN DAN SARAN Kesimpulan}

Berdasarkan analisis isi lambung Ikan Mujair (Oreochormis mossambicus) di Danau Talaga, diperoleh dua kelompok pakan yaitu pakan nabati (Fitoplankton) dan pakan hewani (Zooplankton). Hal ini menunjukkan bahwa ikan mujair termasuk dalam golongan pemakan segala atau omnivora (pemakan hewan dan tumbuhan).

\section{Saran}

Berdasarkan hasil penelitian diharapkan kepada masyarakat agar dapat membudidayakan ikan mujair khususnya di Danau Talaga dan diharapkan pada penelitian selanjutnya menggunakan metode lain untuk menganalisis isi lambung ikan.

\section{DAFTAR RUJUKAN}

Asyari \& Muflikhah, N. (2005). Pengaruh pemberian pakan rucuh berbeda terhadap penumbuhan dan kelangsungan hidup ikan baung dalam sangkar. Jurnal Ilmu-Ilmu Perairan dan Perairan Indonesia, 12(2), 107-112. 
Barani, M.H. (2002). Peranan penting ilmu iktiologi dalam kegiatan usaha penangkapan ikan. Jurnal Iktiologi Indonesia, 2(2), 57-60.

Buwono, N.K., Arfiati, D., \& Arifin, M.S. (2019). Analisis isi lambung ikan tawes di Hilir Sungai Bengawan Solo Kabupaten Lamongan. Journal of Aquaculture and Fish Health, 8(1), 8-14.

Cahyono, B. (2000). Budidaya Ikan Air Tawar. Yogyakarta: Penerbit Kansius.

Cahyono. (2001). Budidaya Ikan Air di Perairan Umum. Yogyakarta: Kanisius.

Effendie, M.I. (2002). Biologi Perikanan. Yogyakarta: Yayasan Pustaka.

Gani, A., Nilawati, J., \& Rizal, A. (2015). Studi habitat dan kebiasaan makanan Ikan Rono Lindu. Jurnal Sains dan Teknologi Tadulako, 4(3), 9-18.

Kalara, E. (2002). Jenis-jenis ikan di Danau Talaga Kabupaten Donggala. [Skripsi]. Palu: Universitas Tadulako.

Mamu, H.D. (2007). Keanekaragam Dan Distribusi Ikan Air Tawar di Perairan Danau Talaga Kabupaten Donggala Sulawesi Tengah. [Skripsi]. Palu: Universitas Tadulako.

Mardlijah, S. (2017). Analisis isi lambung ikan cakalang dan ikan madidihang yang didaratkan di Bitung Sulawesi Utara. Jurnal Penelitian Perikanan Indonesia, 14(2), 227-235.

Odum, E.P. (1994). Dasar-Dasar Ekologi. Yogyakarta: UGM Press.

Pescod, M.B. (2001). Investigation of Rational Effluent and Stream Standard for Tropical Countries. Bangkok: AIT.

Siregar, R.A., Putra, R.M., \& Efizon, D. (2018). Analisis isi lambung ikan baung di Rawa Banjiran Sungai Air Hitam Pekanbaru. Jurnal Perikanan dan Kelautan, (21), 1-15.

Sjafei, D.S. (2001). Kebiasaan makanan dan faktor kondisi ikan kurisi di Perairan Teluk Labuan Banten. Jurnal Ikhtiologi Indonesia Fakultas Perikanan dan Ilmu Kelautan IPB, 1(1), 7-11.

Suprianto, Trianto, M., Alam, N., \& Kirana, N.G.A.G.C. (2020). Karakter morfologi dan analisis daerah conserved gen elongation factor 1a (EF1a) pada Lepidotrigona terminata. Jurnal Metamorfosa, 7(2), 30-39.

Susanto, H. (2004). Budidaya Ikan Pekarangan. Jakarta: Penebar Swadaya.

Titrawani, Elvyra, R., \& Sawalia, R.U. (2013). Analisis isi lambung ikan senangin di Perairan Dumai. Jurnal Biologi Al-Kauniyah, 6(2), 85-91.

Tompodung, E., Worang, F.G., \& Roring, F. (2016). Analisis rantai pasok ikan mujair di Kabupaten Minahasa. Jurnal Ekonomi Sains, 4(3), 20-23.

Tresna, K.L., Dhahiyat, Y., \& Herawati, T. (2012). Kebiasaan makanan dan luas relung ikan hulu Sungai Cimanuk Kabupaten Garut Jawa Barat. Jurnal Perikanan dan Kelautan, 3(3), 163-173.

Trianto, M., \& Marisa, F. (2020). Diversity of bees and wasp (Hymenoptera) in cowpea (Vigna sinensis L.) in agricultural area at Martapura District, Banjar Regency, South Kalimantan. Journal of Science and Technology, 9(2), 29-33.

Trianto, M., \& Purwanto, H. (2020). Molecular phylogeny of stingless bees in the Special Region of Yogyakarta revealed using partial 16S rRNA mitochondrial gene. Buletin Peternakan, 44(4), 186-193.

Trianto, M., \& Purwanto, H. (2020). Morphological characteristics and morphometrics of Stingless Bees (Hymenoptera: Meliponini) in Yogyakarta, Indonesia. Biodiversitas, 21(6), 2619-2628. 
Trianto, M., Kaini, Saliyem, Warsih, E., \& Winarsih. (2020). Keanekaragaman serangga polinator pada tanaman nanas (Ananas comosus (L.) Merr.) di Desa Bincau. Jurnal Penelitian Science dan Pendidikan, 9(2), 154-162.

Trianto, M., Marisa, F., \& Siswandari, N.P. (2020). Kelimpahan nisbi, frekuensi, dan dominansi jenis lalat di beberapa Pasar Tradisional di Kecamatan Martapura. Jurnal Metamorfosa, 7(2), 21-29.

Trianto, M., Marisa, F., \& Sukmawati. (2020). Keanekaragaman jenis rayap pada perkebunan kelapa sawit dan perkebunan karet di Kabupaten Banjar, Kalimantan Selatan. Jurnal Biologi Makassar, 5(2), 199-209.

Utomo, L.N.K.P. (2018). Analisis kualitas air danau Kandung Suli Kabupaten Kapuas Hulu. Jurnal Teknologi Lingkungan Lahan Basah, 6(1), 215-235.

Wulandari. (2006). Kehidupan Dalam Setetes Air. Bandung: ITB Press.

Yeni, E., \& Elvira, R. (2017). Analisis isi lambung ikan selais terang bulan di Desa Rantau Kasih Sungai Kampar Kiri Provinsi Riau. Jurnal Biospecies, 10(2), 44-49. 